\section{HUBUNGAN PANJANG SERI DATA HISTORIK TERHADAP \\ KUALITAS DATA HASIL PREDIKSI PADA PENERAPAN MODEL RANTAI MARKOV UNTUK PERAMALAN ALIRAN SUNGAI}

Sulianto

Staf Pengajar Jurusan Teknik Sipil

Fakultas Teknik - Univ. Muhammadiyah Malang
Kampus III, Jl. Tlogomas No. 246 Telp. (0341) $464318-319$ Pes. 130 Fax. (0341) 460435 e-mail: erwin67pro@yahoo.com

\section{ABSTRACT}

Markov Chain Model is a stochastic model for forecasting the river flow which in his analysi always involves a long series of historical data. In most studies the method is still highly theoretica and not fully applicable significantly due to the limited data in the field.This study is an attempt to optimize the application of Markov Chain Model for its functionality extensively to extrapolate data streams. The scope of this research is basically conducted a study on the relationship between the length of the historical flow data series with data quality prediction results. By knowing these characteristics, the error correction of analysis results can be expected due to data limitations, so that the Markov Chain Model can be widely applied to optimization of waterworks operations.

Results for the Konto River and River showed that the prediction of flow Kwayangan next year with Markov chain models tend to give better results than the results of forecasting by conventional methods are widely applied. Markov model is good enough to predict the river flow has low flow fluctuations, but for a river flow fluctuated sharply less than satisfactory results. The length of data series ranges from 15 to 20 of the optimal inputs to produce a minimum error rate prediction. Accuracy of prediction result is not determined by the length of the input data series, but is determined by the nature of statistical data. Value of lag-1 correlation coefficient are large an small skewness coefficient of the historical data tends to give a satisfactory prediction results.

Key words: river flow, data, prediktion, markov model.

\section{PENDAHULUAN}

Peramalan aliran inflow pada bangunan air untuk setahun kedepan sangat diperlukan dalam merencanakan pola operasinya. Salah satu model peramalan (forecasting) yang telah banyak diaplikasikan untuk berbagai macam keperluan baik pada bidang rekayasa, ekonomi, lingkungan atau bidang lainnya adalah Model Rantai Markov. Model Rantai Markov merupakan model stokastik yang dalam analisisnya melibatkan unsur deterministik dan unsur random untuk mengantisipasi adanya faktor ketidakpastian di alam. Salah satu syarat keberhasilan penerapan Model Markov adalah tersedianya seri data historik yang memadai baik ditinjau dari aspek kuantitas maupun kualitasnya. Semakin panjang seri data historik berarti jumlah titik data latih semakin

komplek dan pola output yang dihasilkan oleh model akan semakin dapat merepresentasikan fenomena yang terjadi sebenarnya.

Kendala utama dalam penerapan Mode Markov secara luas untuk ekstrapolasi data debit adalah terbatasnya jumlah dan kualitas data yang memadai pada sungai-sungai di Indonesia, terutama pada sungai-sungai yang belum dikelola dengan baik. Adanya keterbatasan tersebut upaya untuk mengetahui batasan panjang seri data historik yan dilibatkan sebagai dasar analisis menjadi penting. Dengan mengetahui karakteristik tersebut maka batasan penerapan Model Markov untuk ekstrapolasi data debit dapat dirumuskan dan kemungkinan terjadinya simpangan dari output yang dihasilkan dapat ditekan sekecil mungkin.

Tujuan penelitian ini menyangkut dua hal, yaitu mengetahui hubungan antara panjang seri data

78 |Media Teknik Sipil, Volume 9, Nomor 1, Februari 2011: 78 - 86

historik dan tingkat akurasi dari output yang dihasilkan oleh Model Markov, serta mengetahui panjang seri data historik yang relevan yang dapat memberikan tingkat akurasi yang memadai.

Model Rantai Markov yang dikembangkan menjadi metode Thomas Fiering merupakan suatu metode yang telah lama dikenal untuk membangkitkan data debit sintetis bulanan. Hampi semua buku membahas aplikasi statistika di dalam ilmu hidrologi, misalnya Raudkivi (1981), Kottegoda (1980) atau Shahin (1993) mengemukakan bahwa Metode Markov adalah metode untuk membuat data debit sintetis, jika data debit pengamatan masih kurang panjang (kurang dari 20 tahun) untuk digunakan sebagai masukan dalam simulasi perencanaan wilayah sungai, bentuk dasar dari model Rantai Markov adalah : (Somarto 1987:501)

$\mathrm{q}_{\mathrm{i}}=\mathrm{d}_{\mathrm{i}}+\mathrm{e}_{\mathrm{i}}$

dengan,

$\mathrm{d}=$ komponen deterministic dan

$\mathrm{e}=$ komponen $\mathrm{acak}$

Pengembangan persamaan diatas untuk peramalan debit sintetis untuk musim ganda (mult season) adalah : (Shahin, 1993)

$q_{i, j}=\mu_{j}+\frac{\rho(j) . \sigma_{j}}{\sigma_{j-1}} \quad\left(q_{i, j-1}-\mu_{j-1}\right)+t_{i, j} \sigma_{j} \sqrt{ }\left(1-\rho(j)^{2}\right)$

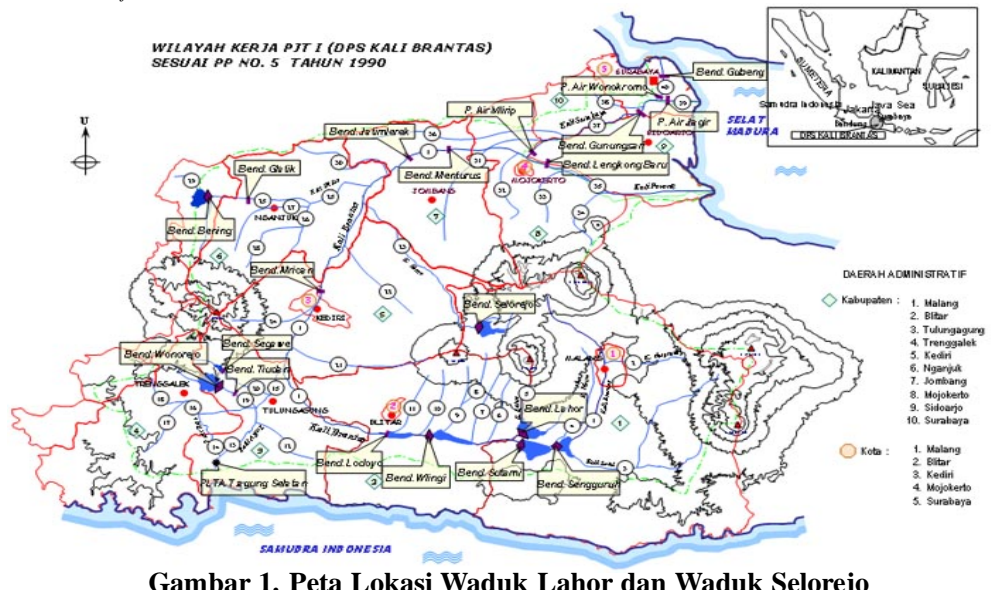

Gambar 1. Peta Lokasi Waduk Lahor dan Waduk Selorejo

Sulianto ${ }^{I}$,Hubungan Panjang Seri Data Historik Terhadap Kualitas Data Hasil Prediksi Pada $\mid 79$ Penerapan Model Rantai Markov Untuk Peramalan Aliran Sungai dimana :

$=$ debit bulanan dalam tahun i $(\mathrm{j}=1,2, \ldots ., 12)$

$=$ rata-rata debit bulan $\mathrm{j}$

$r_{i j} \cdot s_{1} / s_{j-1}=$ koefisien regresi $q_{i, j}$ dari $q_{i j-1}$

$r_{j}=$ koefisien korelasi bulan ke j dari bulan ke j-1

$\mathrm{s}_{\mathrm{j}}=$ simpangan baku bulan ke $\mathrm{j}$

$\mathrm{s}_{\mathrm{j}-1}=$ simpangan baku bulan $\mathrm{j}-1$
$\mathrm{q}_{\mathrm{j}-1}=$ debit rata-rata bulan $\mathrm{j}-1$

$=$ variabel acak berdistribusi normal baku, dengan rata-rata 0 dan variansi 1 , untuk bulan $j$ dengan catatan bahwa untuk $j=1$ (bulan Januari), maka j-1 =12 (Bulan Desember tahun yang lalu)

\section{METODELOGI}

Lokasi Penelitian

Waduk Selorejo secara administratif terletak di Kecamatan Ngantang Kabupaten Malang Jawa Timur. Lokasi Waduk Selorejo berada pada jarak menuju Kota Kediri. Waduk Selorejo berkedudukan di Wilayah Jawa Timur yang secara geografis $12^{\prime}-8^{\circ} 48^{\prime}$ dan pada kedudukan +624.00 meter di atas permukaan air laut. kurang lebih $35 \mathrm{Km}$ ke arah barat Kota Malang terletak pada posisi $111^{\circ}-114^{\circ}$ Bujur Timur dan $7^{\circ}$ 


\section{Tahap Kegiatan Penelitian}

Tahap kegiatan penelitian secara berturutan adalah pengumpulan data, pemeriksaan data, analisis data, pembahasan hasil analisis data serta penarikan kesimpulan dan saran. Data yang digunakan sebagai dasar analisis adalah data historik bulanan yang tercatat pada Stasiun Hidrometri di Sungai Konto dan Sungai Kwayangan. Panjang seri data historik yang dilibatkan adalah 22 tahun, yaitu mulai Tahun 1984 hingga Tahun 2006. Dalam analisisnya seri data tersebut dibagi menjadi dua bagian, yaitu ; seri data Tahun 1984 hingga Tahun 2005 digunakan sebagai data trainning dan seri data Tahun 2006 digunakan sebagai data testing. Selanjutnya sebagai variabel panjang seri data, maka analisisnya menggunakan berbagai masukan data training sepanjang 5,10 , 15, 20 dan 22 Tahun yang merupakan catatan terakhir

\section{Uji Homogenitas Data}

Homogenitas data hasil ekstrapolasi dengan data historik diuji dengan inferensi statistik yang didasarkan pada besaran rerata dan variansi. Untuk maksud ini maka digunakan statistik penguji berdistribusi Student-t test yang didasarkan pada besaran rerata dan Fisher test yang didasarkan pada nilai variansi data.

\section{Uji Unjuk Kerja Model}

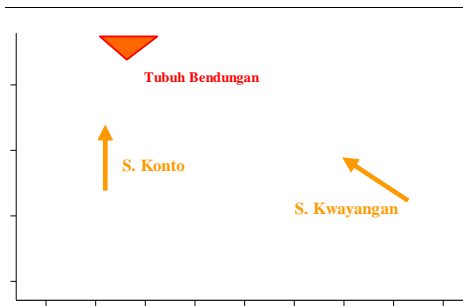

Gambar 2. Map Image Waduk Selorejo
Untuk membandingkan kecocokan hasi peramalan berdasarkan panjang seri data historik $5,10,15,20$ dan 22 Tahun maka digunakan kriteria angka evaluasi root mean square error (RMSE). Root Mean Square Error dipresentasikan sebagai rata-rata kuadrat simpangan (selisih) antara nila keluaran (hasil prediksi) terhadap nilai target (data (esting). Nilai MRSE semakin kecil menunjukkan bahwa rata-rata nilai peramalan yang dihasilkan sangat dekat dengan nilai yang sebenarnya.

\section{HASIL DAN PEMBAHASAN}

\section{Map Image Waduk Selorejo}

Inflow Waduk Selorejo terdiri dari dua sungai, yaitu Sungai Konto dan Sungai Kwayangan sepert ditunjukkan pada Gambar 2 dan 3.

\section{Data Historik Aliran Inflow}

Data debit historik inflow Waduk Selorejo periode 10 harian mulai Bulan Januari Tahun 1984 Hingea Tahun 2006 ditunjukkan pada Gambar 6. Debit Sungai Konto secara kuantitatif jauh lebih besar dari nilai debit Sungai Kwayangan. Hal ini bisa dimengerti oleh karena Sungai Kwayangan merupakan anak sungai Konto dengan perbandingan luas DAS (daerah aliran sungai) kurang lebih seperempatnya. Adanya aliran daser (base flow) yang relatif cukup besar menunjukkan bahwa DAS Konto masih cukup baik ditinjau dari fungsinya sebagai konservasi air.

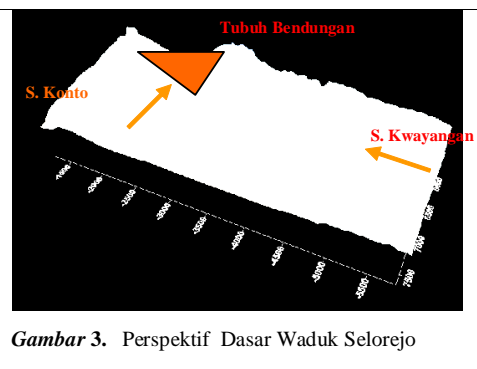

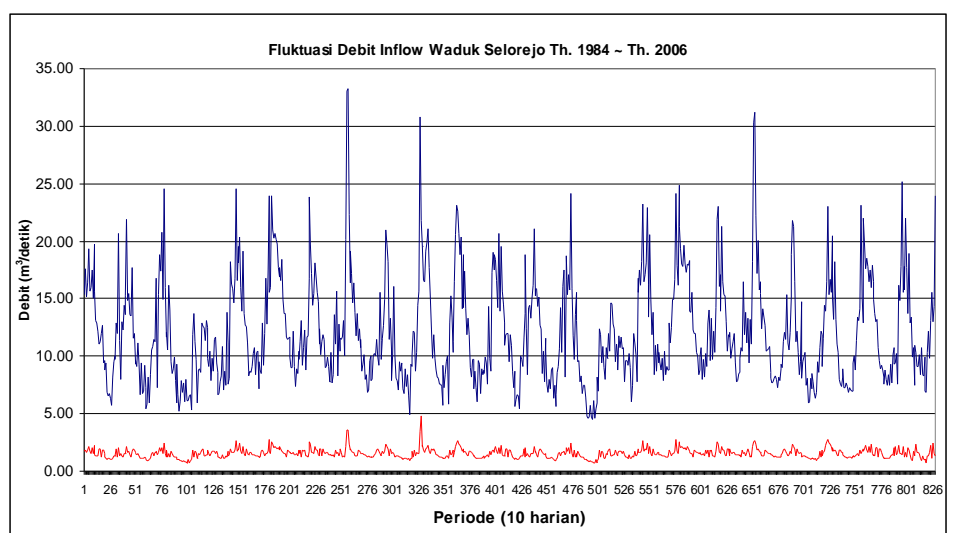

Gambar 4. Fluktuatif Debit Inflow Waduk Selorejo Th. 1984-2006

Prediksi Aliran Dengan Model Rantai Markov Prediksi Prediksi aliran Tah 20 dan 22 Tahun terakhir pada Sungai Konto da Sungai Kwayangan secara rinci disajikan pada bagian lampiran, dan secara ringkas disajikan pada Gambar 5 dan Gambar 6. Prediksi aliran Tahun 2006 pada Sungai Konto dan Sungai Kwa dengan menggunakan input seri data yan bervariasi $5,10,15,20$ dan 22 Tahun secara

kuantitatif menunjukkan perbedaan yang cukup signifikan, namun masing-masing cenderung memiliki pola yang hampir sama. Panjang seri data terlihat tidak memiliki kecenderungan tertentu terhadap nilai debit rerata, debit minimum dan debit maksimum, namun tidak demikian pada nilai (ilai variasi yang dihasilkan cenderung lebih besar seiring dengan semakin panjangnya seri data debit yang dilibatkan dalam perhitungan.

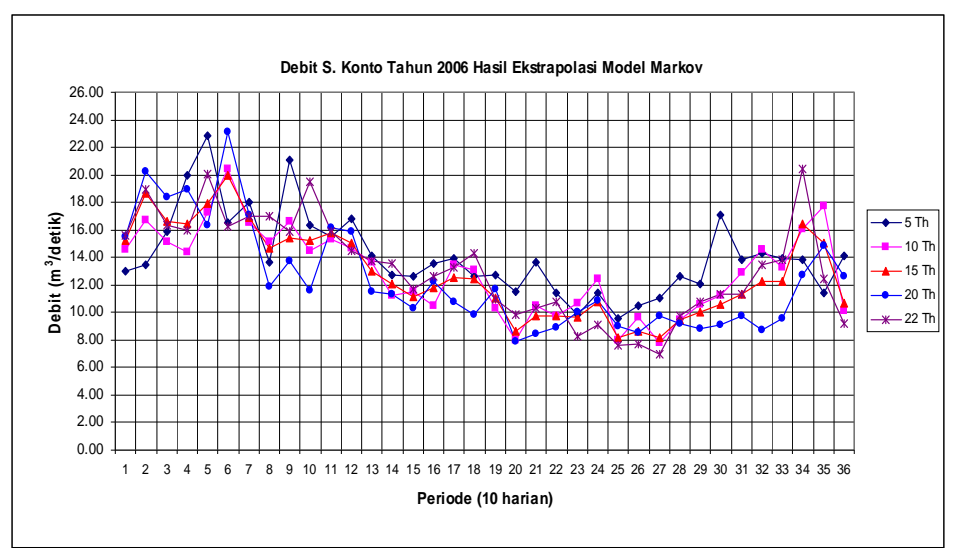

Gambar 5. Debit S. Konto Tahun 2006 Hasil EkstrapolasiModel Markov 


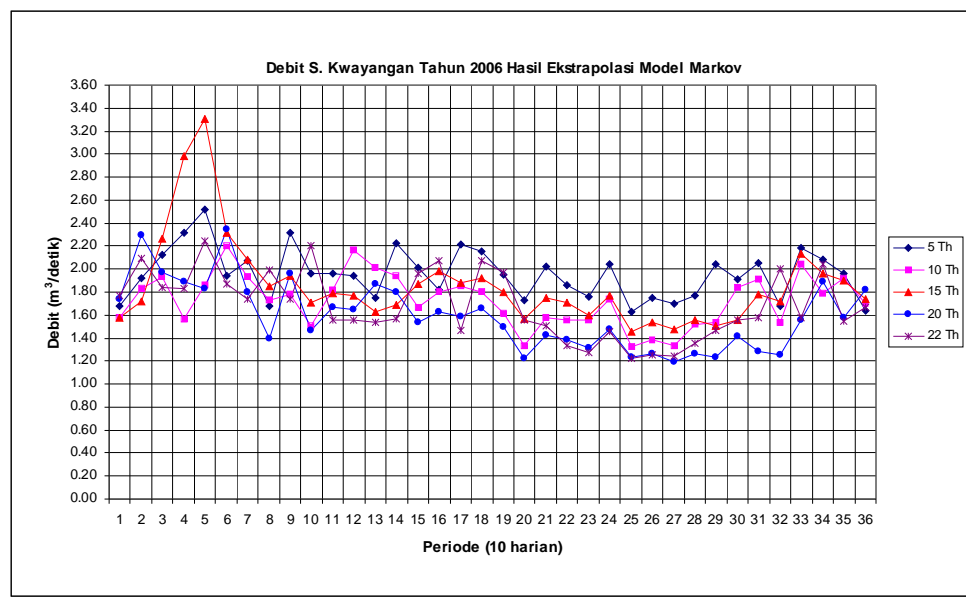

Gamber 6. Debit S. Kwayangan Tahun 2006 Hasil EkstrapolasiModel

\section{Uji Kecocokan Hasil Prediksi}

\section{Uji kecocokan hasil prediksi aliran S. Konto}

Pola yang menunjukkan perbandingan nilai rasio dari setiap teknik analisis yang diteliti secara grafis ditunjukkan pada Gambar 7. Hasil tersebut menunjukkan bahwa nilai minimum dari jumlah rasio sebesar 32,51 dan nilai minimum 0,57 diberikan oleh teknik prediksi dengan menggunakan data historik dari periode sebelumnya, rasio rata-rata sebesar 0,89 ditunjukkan oleh teknik rata-rata data historik dan rasio maksimum 1,18 ditunjukkan oleh teknik prediksi dengan Model Markov menggunakan masukan panjang seri data 15 Tahun.

Gambar 8 menunjukkan adanya kecenderungan bahwa hasil prediksi aliran Tahun 2006 di Sungai Konto dengan mengounakan Model Markov memiliki dibanding metode konvensional, kecuali pada analisis yang menggunakan panjang seri data debit 20 Tahun. Kondisi tersebut menunjukkan bahwa teknik peramalan aliran setahun kedepan dengan menggunakan Model Markov adalah lebih baik dibanding cara rata-rata dan penggunaan data pada periode sebelumnya. Pada penerapan Model Markov terlihat tidak adanya kecenderungan

82 |Media Teknik Sipil, Volume 9, Nomor 1, Februari 2011:78 -86 diperoleh seiring dengan panjang seri data yang Kondisi tersebut juga dapat mematahkan sementara dilibatkan dalam analisis. Penggunaan panjang seri dugaan bahwa semakin panjang seri data historik data historik 10 Tahun sebagai masukan data yang dilibatkan dalam analisis dapat memberikan memberikan nilai RMSE yang paling optimal. hasil prediksi yang semakin baik.

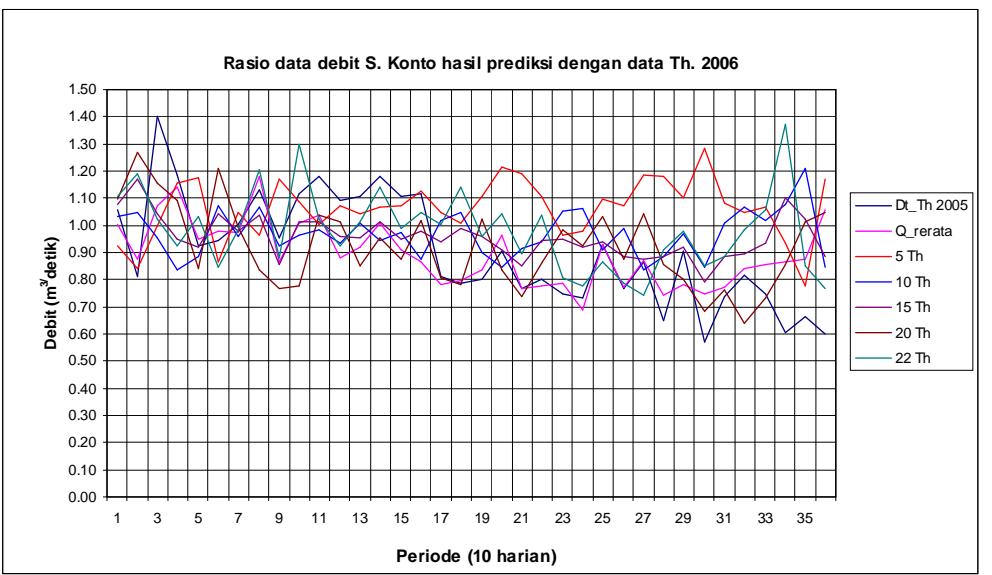

Gambar 7. Rasio Data Debit S. Konto Hasil Prediksi Dengan Data Tahun 2006

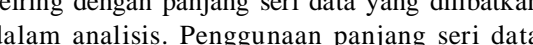
historik 10 hingga 15 Tahun sebagai masukan data memberikan nilai RMSE yang paling optimal. Fenomena tersebut dapat mematahkan sementara dugaan bahwa semakin panjang seri data historik yang dilibatkan dalam analisis dapat memberikan hasil prediksi yang semakin baik.

Uji kecocokan hasil prediksi aliran Sunga Kwayangan

Rasio nilai aliran prediksi dan data amatan ditunjukkan pada Gambar 9, dan hubungan antara panjang se pada Gambar 10. Gambar tersebut menunjukkan adanya kecenderungan bahwa hasil prediksi aliran Tahun 2006 di Sungai Kwayangan dengan menggunakan Model Markov memiliki nilai RMSE yang lebih kecil dibanding hasil dari metode konvensional. Kondisi tersebut menunjukkan peraman aliran setahun kedepan dengan menggunakan Model Markov adalah lebih baik dari cara rata-rata data historik dan penggunaan data pada periode sebelumnya. Pada penerapan Model Markov terlihat tidak menunjukkan adanya kecenderungan semakin baiknya hasil prediksi yang

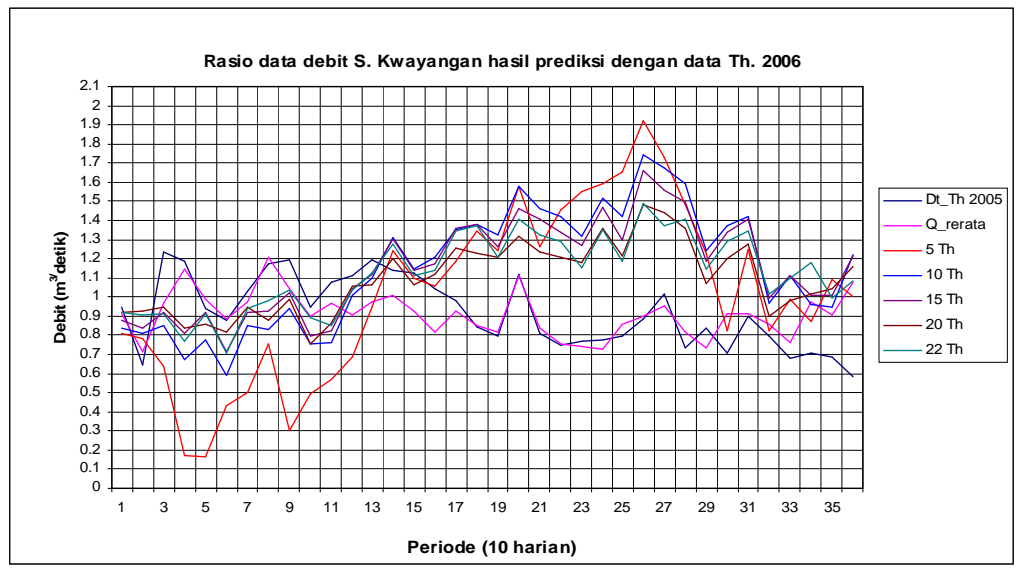

Gambar 8. Rasio Data Debit S. Kwayangan Hasil Prediksi Dengan Data Tahun 2006

Suliantol, Hubungan Panjang Seri Data Historik Terhadap Kualitas Data Hasil Prediksi Pada $\mid \mathbf{8 3}$ Penerapan Model Rantai Markov Untuk Peramalan Aliran Sungai 


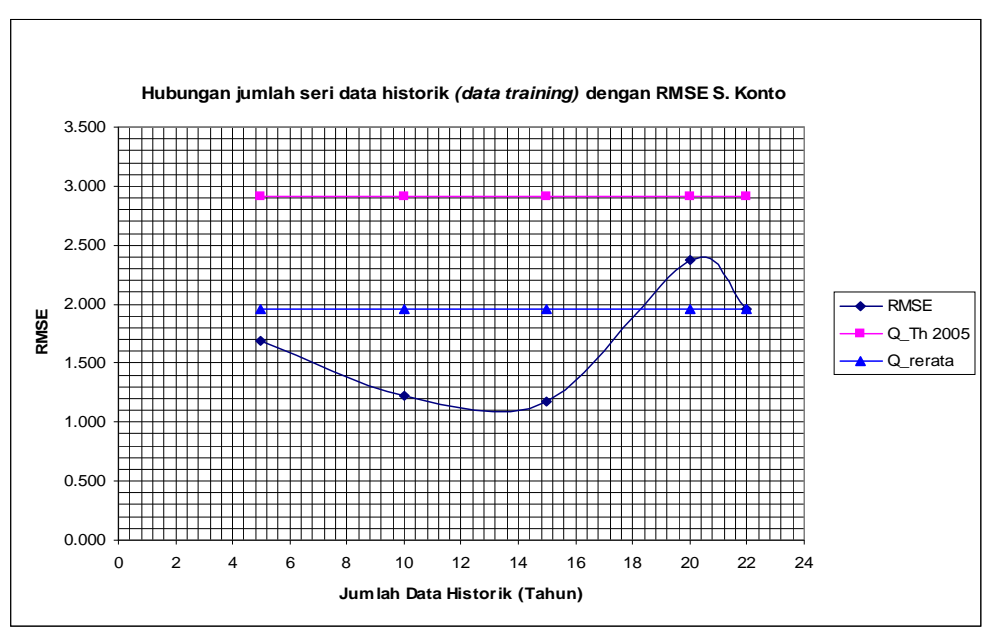

Gambar 9. Hubungan Jumlah Seri Data Historik (data training) Dengan RSME S. Konto

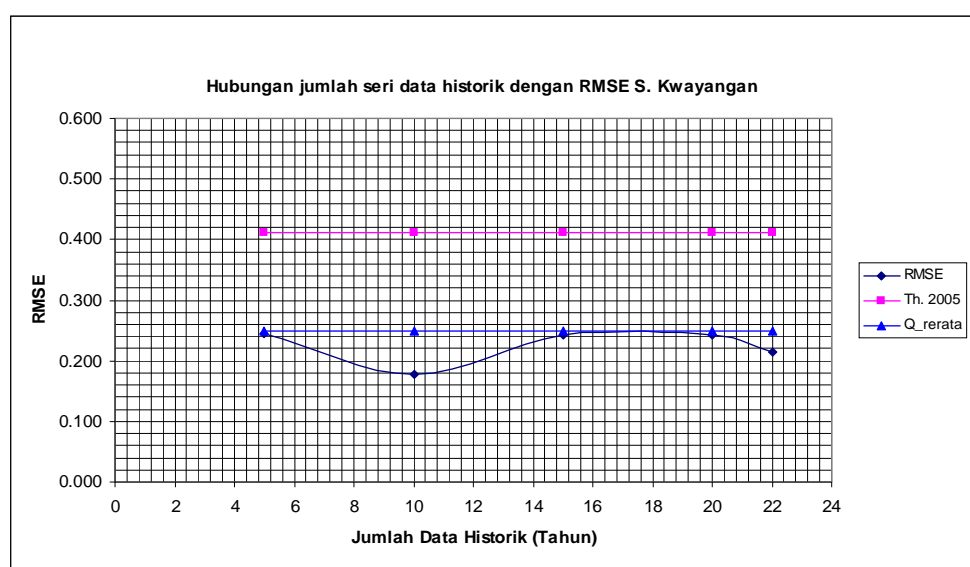

Gambar 10. Hubungan Jumlah Seri Data Historik (data training) Dengan RSME

S. Kwayangan

\section{KESIMPULAN}

- $\quad$ Aliran Tahun 2006 hasil ekstrapolasi Model Rantai Markov dengan masur historik tahun dan 22 Tahun menunjukkan pola yang secara kualitatif hampir sama. Pola aliran yang dihasilkan rata-rata memiliki hasil yang lebih

baik bila dibandingkan dengan hasil ekstrapolasi dari teknik peramala konvensional.

Dugaan sementara bahwa semakin panjang seri data historik dapat memberikan hasi prediksi yang semakin baik adalah tidak terbukti pada data aliran di S. Konto dan S. Kwayangan. Panjang seri data kurang dari 10 Tahun dan lebih dari 15 Tahun cenderung

84 |Media Teknik Sipil, Volume 9, Nomor 1, Februari 2011:78 - 86 memberikan tingkat RMSE yang relatif besar. Fenomena tersebut menunjukkan bahwa bukan kuantitas data yang menentukan tingkat akurasi hasil perhitungan namun kualitasnya yang diindikasikan dengan sifat-sifat statistik tertentu. Hasil lain menunjukkan bahwa Model Markov tidak cukup responsif dalam mengantisipasi kemungkinan terjadinya debi ekstrim yang terjadi secara tiba-tiba.

- Hasil analisis dari data aliran S. Konto dan S. Kwayangan menunjukkan bahwa panjang ser data optimal untuk menghasilkan simpangan minimum pada penerapan Model Markov adalah 10 hingga 15 Tahun.

\section{Saran pada kasus ini adalah :}

- Penerapan Model Rantai Markov untuk peramalan aliran sungai setahun kedepan dapa memberikan hasil yang lebih baik dari metode peramalan konvensional, namun analisisnya harus dilakukan dengan hati-hati. Penggunaan seri data yang panjang belu memberikan hasil yang memuaskan, dan penggunaan data dengan panjang seri yang sangat terbatas mungkin masih dapat ditolerir hanya bila data tersebut menunjukkan tingkat keseragaman yang memadai dan memilik sebaran yang mendekati distribusi normal.

- Penerapan Model Rantai Markov untuk analisis aliran sungai yang memiliki sifa temporary flow sebaiknya dihindarkan mengingat kelemahannya dalan mengantisipasi terjadinya fluktuasi aliran yan ekstrim. Pada kasus ini disarankan untuk mempertimbangkan metode peramalan yang lain. Perkembangan teknik pemodelan matematika yang pesat dapat memberi peluang yang cukup besar untuk dapat dikembangkan sebagai teknik peramalan alternatif guna memperoleh hasil yang lebih baik. Dalam kaitan ini pengembangan model berbasi kecerdasan buatan "artificial intelegentia" merupakan pilihan yang cukup relevan.

\section{Ucapan terima kasih}

Penulis mengucapkan terima kasih kepada Universitas Muhammadiyah Malang melalui Lemlit-UMM yang telah memberikan segala fasilitas atas penyelesaian penelitian ini, PERUM JASA TIRTA I Malang atas kerjasamanya dalam penyediaan data dan semua pihak yang telah memberikan segala masukan untuk penyempurnaan penelitian ini. Semoga hasil penelitian ini dapat bermanfaat bagi semua pihak.

\section{DAFTAR PUSTAKA}

Boediono \& Koster, 2004, Teori dan Aplikasi Statistik dan Probabilitas PT Remaja Rosdakarya, Bandung.

Linsley, Ray K., dan Franzini, Joseph B. 1991 Teknik Sumber Daya Air Jilid I Diterjemahkan oleh Djoko Sasongko : Penerbit Erlangga.

Kottegoda, N.T., 1980, Stochastic Water Resources Technology, Mac Millian, London.

Hatmoko, W., 2001, Peramalan Debit Aliran Sungai di Bendung Sampean Baru dengan Air Tepat Waktu, Seminalan Alokasi Air Tepat Waktu, Seminar Pengelolaan Sungai Terpadu, Institut Pertanian Bogor, Bogor.

Phien, 1993. Kowater, Kedung Ombo Water Management Model, Directorate General of Water Resources, Jakarta.

Shahin, M., H.J.L. van Oorschot, S.J. Lange, 1993, Statistical Analysis in Water Resources Engineering, AA. Balkema, Rotterdam.

Raudkivi, A.J., 1981. Advanced Introduction to Hydrology, Pergamon Press.

Suliantol, Hubungan Panjang Seri Data Historik Terhadap Kualitas Data Hasil Prediksi Pada $\mid \mathbf{8 5}$ Penerapan Model Rantai Markov Untuk Peramalan Aliran Sungai 
Soemarto, CD, 1987. Hidrologi Teknik : Penerbit Usaha Nasional.

Waluyo \& Amirwandi, 2001, Penerapan Metode

Thomas-Fiering Untuk Peramalan Debit
Sungai Cimanuk di Bendung Rentang,

Sungai Cimanuk di Bendung Rentang,
Prosiding Kongres VII \& Pertemuan Ilmiah

Tahunan (PIT) XVIII HATHI, Malang

86 |Media Teknik Sipil, Volume 9, Nomor 1, Februari 2011: 78 - 86 